\title{
CATALYTIC STEAM REFORMING OF TOLUENE POST- GASIFICATION USING AS MODEL COMPOUND OF TAR PRODUCED BY BIOMASS GASIFICATION
}

\author{
J. D. SILVA*, C.C.B. OLIVEIRA AND C. A. M. ABREU \\ ${ }^{1}$ Polytechnic School - UPE, Laboratory of Environmental and Energetic Technology; Rua \\ Benfica - 455, Madalena, Recife - PE, Brazil. Cep: 50750-470, phone: (81) 3183-7515; \\ Corresponding author: E-mail address:*jornandesdias@poli.br \\ 2 Department of Chemical Engineering, Federal University of Pernambuco (UFPE), Phone (81) \\ 2126-8901, R. Prof. Artur de Sá, 50740-521, Recife - PE Brazil. E-mail address: cesar@ufpe.br

\begin{abstract}
The study presents a mathematical model to analyze the dynamic evolution of molar concentrations of toluene $\left(\mathrm{C}_{7} \mathrm{H}_{8}\right)$, water vapor $\left(\mathrm{H}_{2} \mathrm{O}\right)$ carbon monoxide $(\mathrm{CO})$, hydrogen $\left(\mathrm{H}_{2}\right)$, methane $\left(\mathrm{CH}_{4}\right)$ and carbon dioxide $\left(\mathrm{CO}_{2}\right)$ in a catalytic reactor of fixed bed. The mathematical model was discretized using the method of lines (MDLs) to transform the system of partial differential equations (PDEs) in a system of ordinary differential equations (ODEs). The system of ODEs has been solved by the implementation of the method of Runge-Kutta Gill to estimate the chemical species $\mathrm{C}_{7} \mathrm{H}_{8}$, $\mathrm{H}_{2}, \mathrm{CO}, \mathrm{H}_{2}, \mathrm{CH}_{4}$ and $\mathrm{CO}_{2}$. The estimation allows the quantification of individual forecasts of the variables presented in this study. However, valuable information can be obtained from the estimated behaviors in catalytic fixed bed reactor. The model has allowed the validation of chemical species $\left(\mathrm{H}_{2}, \mathrm{CO}\right.$ and $\left.\mathrm{CO}_{2}\right)$ by comparing the optimized values. Additionally, the concentrations for chemical species $\mathrm{C}_{7} \mathrm{H}_{8}, \mathrm{H}_{2}, \mathrm{CO}, \mathrm{H}_{2}, \mathrm{CH}_{4}$ and $\mathrm{CO}_{2}$ was studied.
\end{abstract}

\section{INTRODUCTION}

The global interest with the depletion of fossil fuels and rising environmental problems associated with the use of these sources has attracted the attention of researchers to develop new processes for power generation based on renewable sources. Biomass has been considered a renewable energy source. Alternatively, the biomass can be converted into gaseous fuel through gasification technology. The gasification of biomass is a promising technology for power generation and chemical productions. A major problem for commercialization of biomass gasification is the quality of the gas produced (post-gasification gas). Among the impurities present in the postgasification gas, tar is a serious problem for the gas produced from biomass.

Normally, the gas produced into the fixed bed or fluidized gasifiers contains about $10 \%$ to $20 \%$ of tar with $14.2 \%$ toluene, $13.9 \%$ of hydrocarbon with one aromatic ring, $9.6 \%$ naphthalene, $7.8 \%$ of hydrocarbons with two aromatic rings, $3.6 \%$ of hydrocarbons with three aromatic rings, $0.8 \%$ of hydrocarbons with four aromatic rings, $4.6 \%$ of phenolic compounds, $6.5 \%$ of heterocyclic 


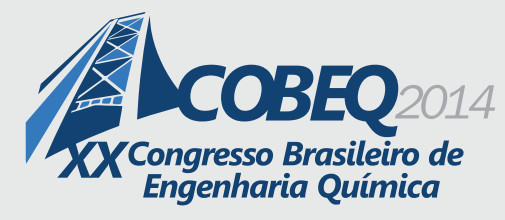

19 a 22 de outubro de 2014

Florianópolis/SC

compounds and $1 \%$ others. The removal or destruction of tar is seen as one of the major technical challenges to be overcome for the commercial success of advanced gasification technologies. According Bona et al., (2008), the catalytic reforming of tar increases the calorific value of the gas produced and the overall efficiency of the thermochemical conversion process. Toluene being the main component of tar, the present work has been focused on modelling of steam reforming of toluene (SRT) in a catalytic reactor of fixed bed (LF).

A complete description of the process of mixing $\left(\mathrm{H}_{2} \mathrm{O}+\right.$ toluene) in diluent gas (Ar) of solid catalytic particles in the catalytic reactors of LF involves hydrodynamic aspects of this mixture. Among these aspects, there is heat transfer from the gas-solid interphase, mass transfer from the gassolid interphase, diffusion of chemical components into the pores of the catalyst and the gas-solid interactions such as adsorption, desorption and reaction. Emphasizing the modelling of catalytic reactors of LF, refers to the application of able dynamic models to describe the phenomenology of realistic transient and stationary regimes, enabling secure and reliable reviews on control and process optimization (Silva and Abreu, 2012).

The mathematical modelling and computer simulation for the catalytic reactors of LF are in continuous development, aiming to improve knowledge of the phenomenological processes of this equipment. As its applications, the catalytic reactors of LF are applied in the process of the chemical, biochemical, petrochemical and oil refineries to process hydrodesulfurization, hydrotreatment and hydrocracking (Silva, 2012).

The main objective of this paper was the development of a dynamic mathematical model to study isothermal steam reforming of toluene in a catalytic reactor of LF. The model has allowed a validation of chemical species $\left(\mathrm{H}_{2}, \mathrm{CO}\right.$ and $\left.\mathrm{CO}_{2}\right)$ by comparing the optimized values. Additionally, the net rates of chemical species $\left(\mathrm{C}_{7} \mathrm{H}_{8}, \mathrm{H}_{2}, \mathrm{CO}, \mathrm{H}_{2}, \mathrm{CH}_{4}\right)$ were studied as well as the concentrations for chemical species $\left(\mathrm{C}_{7} \mathrm{H}_{8}, \mathrm{H}_{2}, \mathrm{CO}, \mathrm{H}_{2}, \mathrm{CH}_{4}\right.$ and $\left.\mathrm{CO}_{2}\right)$.

\section{MATERIALS AND METHODS FOR THIS RESEARCH}

A conceptual schematic of the catalytic reactor of LF was developed to investigate the SRT according to the Figure 1. For this work, toluene was selected as one tar model compound which will be analyzed at different temperatures $\left(750-900^{\circ} \mathrm{C}\right)$.

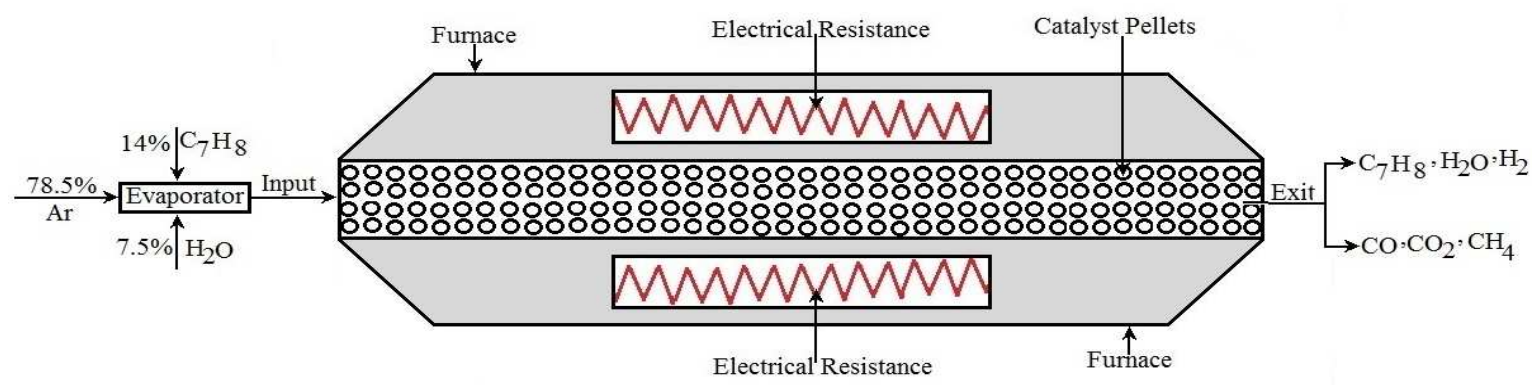

Figure 1: schematic of the CFBR for the SRT 


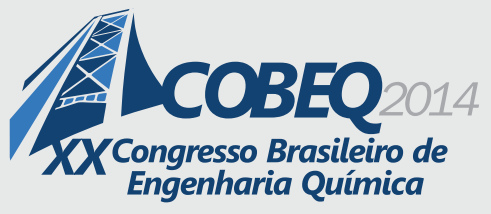

\subsection{Kinetic Mechanism}

The kinetic models treat the mechanisms, rates of chemical reactions and the resulting concentrations of chemical species at any point in time and space of a system. These models are generally related to specific processes, providing important considerations for relating the mechanisms of reactions and ways to increase the rate of a reaction or process. The process discussed here has involved the main reactions of steam reforming of toluene. In normal operation, the reaction (1) is the steam reforming of toluene, the reaction (2) presents the partial steam reforming reaction of methane and (3) shows the reaction water-gas Shift. The reaction (1) is an irreversible reaction, while the reactions (2) and (3) are reversible (equilibrium) as follows.

$$
\begin{aligned}
& \mathrm{C}_{7} \mathrm{H}_{8}+7 \mathrm{H}_{2} \mathrm{O} \rightarrow 7 \mathrm{CO}+11 \mathrm{H}_{2} ; \Delta \mathrm{H}_{298 \mathrm{~K}}^{\mathrm{O}}=+869,17 \mathrm{~kJ} \mathrm{~mol}^{-1} \\
& \mathrm{CH}_{4}+\mathrm{H}_{2} \mathrm{O} \leftrightarrow \mathrm{CO}+3 \mathrm{H}_{2} ; \Delta \mathrm{H}_{298 \mathrm{~K}}^{O}=+206,12 \mathrm{~kJ} \mathrm{~mol}^{-1} \\
& \mathrm{CO}+\mathrm{H}_{2} \mathrm{O} \leftrightarrow \mathrm{CO}_{2}+\mathrm{H}_{2} ; \Delta \mathrm{H}_{298 \mathrm{~K}}^{O}=-41,17 \mathrm{~kJ} \mathrm{~mol}^{-1}
\end{aligned}
$$

Thermodynamically, the reactions (1) and (I2) are endothermic and the reaction (3) is exothermic. The components of these reaction models are defined as toluene $\left(\mathrm{C}_{7} \mathrm{H}_{8}\right)$, water $\left(\mathrm{H}_{2} \mathrm{O}\right)$, carbon monoxide $(\mathrm{CO})$, hydrogen $\left(\mathrm{H}_{2}\right)$, methane $\left(\mathrm{CH}_{4}\right)$ and carbon dioxide $\left(\mathrm{CO}_{2}\right)$. The stoichiometric coefficients for these model components have been presented in Table 1.

Table 1: Stoichiometric coefficients $v_{\mathrm{ij}}$ of the components of the reactions

\begin{tabular}{|l|l|l|l|l|l|l|}
\hline Reactions & $\mathrm{C}_{7} \mathrm{H}_{8}$ & $\mathrm{H}_{2} \mathrm{O}$ & $\mathrm{CO}$ & $\mathrm{H}_{2}$ & $\mathrm{CH}_{4}$ & $\mathrm{CO}_{2}$ \\
\hline 1 & -1 & -7 & +7 & +11 & 0 & 0 \\
\hline 2 & 0 & -1 & +1 & +3 & -1 & 0 \\
\hline 3 & 0 & -1 & -1 & +1 & 0 & +1 \\
\hline
\end{tabular}

\subsection{Kinetic Modelling}

The kinetic mathematical model presented here considers only three homogeneous reactions according to the reactions (1), (2) and (3) for the SRT. The overall rates for chemical reactions (1), (2) and (3) are presented below with their respective kinetic parameters.

$$
\begin{aligned}
& R_{1}=8.723 \times 10^{9} C_{C_{7} H_{8}} ;\left(\mathrm{kg}_{\mathrm{cat}} \mathrm{s}\right)^{-1} \\
& R_{2}=3.101 \exp \left(-\frac{15.000}{T_{g}}\right)\left[C_{\mathrm{CH}_{4}} C_{\mathrm{H}_{2} \mathrm{O}}-\frac{C_{C O} C_{\mathrm{H}_{2}}^{2}}{0.0265 \exp \left(\frac{32.900}{T_{g}}\right)}\right] ;\left(\mathrm{kg}_{\mathrm{cat}} \mathrm{s}\right)^{-1}
\end{aligned}
$$




$$
R_{3}=250.000 \exp \left(-\frac{138.000}{T_{g}}\right)\left[C_{C O} C_{\mathrm{H}_{2} \mathrm{O}}-\frac{C_{\mathrm{CO}_{2} C_{\mathrm{H}_{2}}}}{0.0265 \exp \left(\frac{3966.000}{T_{g}}\right)}\right] ;\left(\mathrm{kg}_{\mathrm{cat}} \mathrm{s}\right)^{-1}
$$

The net rates, $r_{i}$, for each component type of the reactions (1), (2) and (3) have been obtained using the following equation (Oliveira and Silva, 2012).

$$
r_{i}=\sum_{j=1}^{n} v_{i j} R_{j}
$$

Where, $r_{i} \rightarrow$ the net rate of component $\mathrm{I}, v_{i j} \rightarrow$ the stoichiometric coefficient of the reactions and $R_{j} \rightarrow$ the reaction rates. From the Eq. (7), we get to obtain $\mathrm{r}_{\mathrm{C}_{7} \mathrm{H}_{8}}, \mathrm{r}_{\mathrm{H}_{2} \mathrm{O}}, \mathrm{r}_{\mathrm{CO}}, \mathrm{r}_{\mathrm{H}_{2}}, \mathrm{r}_{\mathrm{CH}_{4}}$ and $\mathrm{r}_{\mathrm{CO}_{2}}$ as follows.

- net rate of $\mathrm{C}_{7} \mathrm{H}_{8}$;

$$
r_{C_{7} H_{8}}=-R_{1}
$$

- net rate of $\mathrm{H}_{2} \mathrm{O}$;

$$
r_{\mathrm{H}_{2} \mathrm{O}}=-\left(7 R_{1}+R_{2}+R_{3}\right)
$$

- net rate of $\mathrm{CO}$;

$$
r_{C O}=7 R_{1}+R_{2}-R_{3}
$$

- net rate of $\mathrm{H}_{2}$;

$$
r_{H_{2}}=\left(11 R_{1}+3 R_{2}+R_{3}\right)
$$

- net rate of $\mathrm{CH}_{4}$;

$$
r_{\mathrm{CH}_{4}}=-\mathrm{R}_{2}
$$

- net rate of $\mathrm{CO}_{2}$;

$$
r_{\mathrm{CO}_{2}}=+R_{3}
$$

\subsection{MODEL FOR THE CATALYTIC REACTOR OF LF}

The mathematical modelling can act significantly to explain the evolution of model components of chemical reactions (1), (2) and (3) in catalytic reactor of LF. For this work, the equations of the model components involved terms of chemical species accumulation, convection of chemical species, dispersions of chemical species and the net rates of model component in the work reactions considered for the process (Oliveira and Silva, 2012). Based on these assumptions, a simplified mathematical model for the catalytic reactor of LF is formulated by the simplified equations of model components which describe the dynamic behavior. In the reaction 


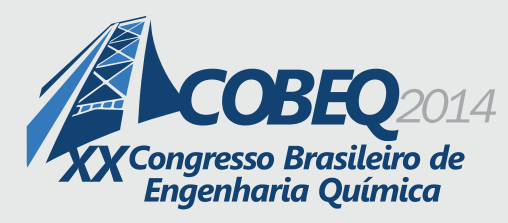

19 a 22 de outubro de 2014

Florianópolis/SC

zone of the catalytic reactor of LF, the mass balance equations of the model components of the reactions (1), (2) and (3) (reactants and products) have been described as follows.

- Mass balance of the model components

$$
\varepsilon_{g} \frac{\partial C_{i}}{\partial t}+\varepsilon_{g} \frac{4 Q_{g}}{\pi d_{c}^{2}} \frac{\partial C_{i}}{\partial z}=\varepsilon_{g} D_{i} \frac{\partial^{2} C_{i}}{\partial z^{2}}+\left(1-\varepsilon_{s}\right) \sum_{j=1}^{3} \sum_{i=1}^{6} \eta_{j} r_{i}
$$

- Initial and boundary conditions of the model components;

$$
\begin{aligned}
& \left.C i\right|_{t=0}=C_{i, 0} \text {; for all } z \\
& \left.D_{i} \frac{\partial C_{i}}{\partial z}\right|_{z=0^{+}}=\frac{4 Q_{g}}{\pi d_{c}^{2}}\left[\left.C_{i}\right|_{z=0^{+}}-C_{i, 0}\right] ; \text { for } t \geq 0 \\
& \left.\frac{\partial C_{i}}{\partial z}\right|_{z=L^{+}}=0 ; \text { for } t \geq 0
\end{aligned}
$$

Where $\mathrm{i}=\mathrm{C}_{7} \mathrm{H}_{8}, \mathrm{H}_{2} \mathrm{O}, \mathrm{CO}, \mathrm{H}_{2}, \mathrm{CH}_{4}$ and $\mathrm{CO}_{2}, j=1,2$ and 3 (reactions).

\section{RESULTS}

The mathematical model was developed to analyze the molar concentrations of chemical species $\left(\mathrm{C}_{7} \mathrm{H}_{8}, \mathrm{H}_{2} \mathrm{O}, \mathrm{CO}, \mathrm{H}_{2}, \mathrm{CH}_{4}\right.$ and $\left.\mathrm{CO}_{2}\right)$. The developed model for this study was used to analyze the evolution of chemical species over time variable at the output of the catalytic reactors of LF. In the simulation, the Computational code has been fed with parameters shown in the Table 2. In this table, it was shown the operational parameters in the reaction region of the catalytic reactors of LF. These parameters of the Table 2 have been admitted as fixed values.

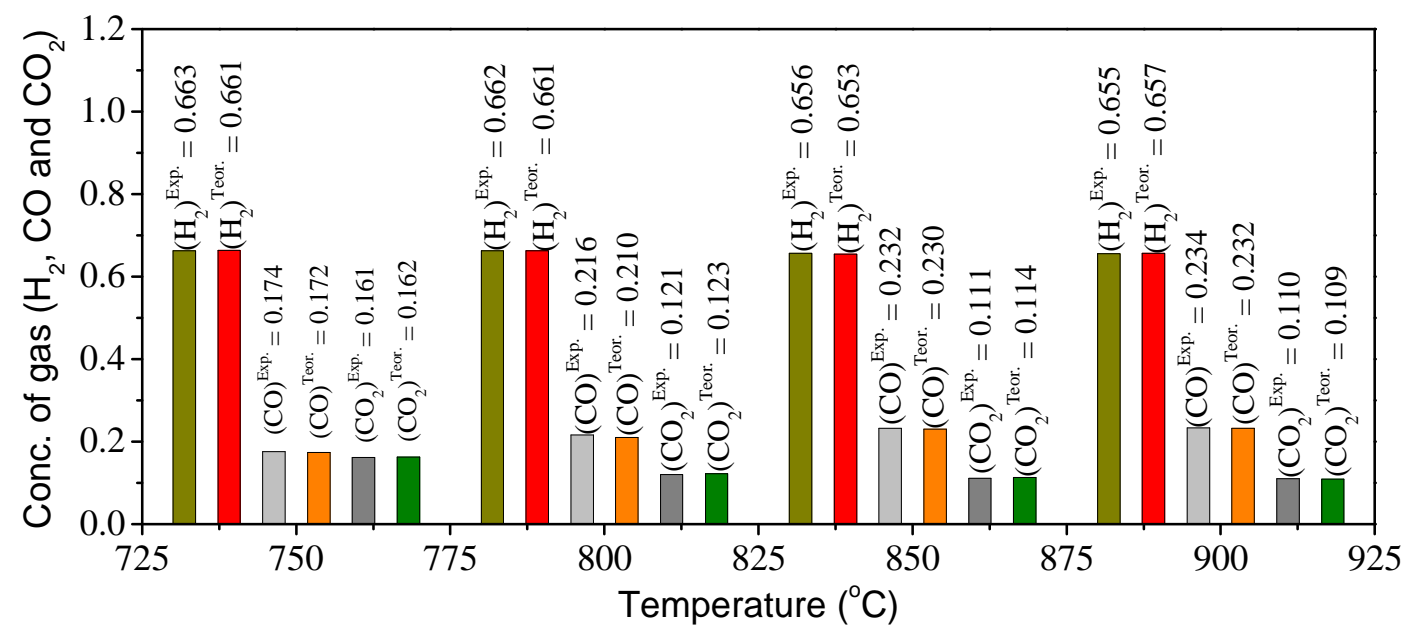

Figure 2: Comparison between experimental data of Zhao et al.(2010) and the results of this optimized study for four different temperatures $\left(750^{\circ} \mathrm{C}, 800^{\circ} \mathrm{C}, 850^{\circ} \mathrm{C}\right.$ and $\left.900^{\circ} \mathrm{C}\right)$ with $\mathrm{Q}_{\mathrm{g}}=$ $2.367 \times 10^{-2} \mathrm{~m}^{3} \mathrm{~s}^{-1}, \mathrm{Q}_{\mathrm{v}}=2.561 \times 10^{-2} \mathrm{~m}^{3} \mathrm{~s}^{-1}$ and $\mathrm{z}=1 \mathrm{~m}$ at the output of the $\mathrm{LF}$ 
Figure 2 shows the comparative experimental data of the literature and data of the present study optimized. The comparison shows a good fit of the experimental and optimized for the gases $\mathrm{H}_{2}, \mathrm{CO}$ and $\mathrm{CO}_{2}$.

Table 2: Operating conditions, properties of the gas and solid phases used in the simulation were extracted of the following references (Silva, 2012; Zhao et al, 2010; Yao et al. 2007)

\begin{tabular}{|c|c|c|}
\hline Categories & Properties & Numerical Values \\
\hline Operation Conditions & $\begin{array}{l}\text { Operation temperature of the gas phase, } \mathrm{Tg}^{\circ} \mathrm{C} \\
\text { Operation temperature of the solid phase, } \mathrm{Ts}{ }^{\circ} \mathrm{C} \\
\text { Operation pressure, } \mathrm{P}_{\text {op }} \text { atm } \\
\text { Gas flow rate, } \mathrm{Q}_{\mathrm{g}} \mathrm{m}^{3} \mathrm{~s}^{-1} \\
\text { Flow of water vapor, } \mathrm{Q}_{\mathrm{v}} \mathrm{m}^{3} \mathrm{~s}^{-1} \\
\text { Initial concentration of } \mathrm{C}_{7} \mathrm{H}_{8}, \mathrm{C}_{\mathrm{C} 7 \mathrm{H} 8,0} \mathrm{~kg} \mathrm{~m}^{-3} \\
\text { Initial concentration of } \mathrm{H}_{2} \mathrm{O}, \mathrm{C}_{\mathrm{H} 2 \mathrm{O}, 0 \mathrm{~kg} \mathrm{~m}^{-3}} \\
\text { Initial concentration of } \mathrm{CO}, \mathrm{C}_{\mathrm{CO}, 0} \mathrm{~kg} \mathrm{~m}^{-3} \\
\text { Initial concentration of } \mathrm{H}_{2}, \mathrm{C}_{\mathrm{H} 2,0} \mathrm{~kg} \mathrm{~m}^{-3} \\
\text { Initial concentration of } \mathrm{CH}_{4}, \mathrm{C}_{\mathrm{CH} 4,0} \mathrm{~kg} \mathrm{~m}^{-3} \\
\text { Initial concentration of } \mathrm{CO}_{2}, \mathrm{C}_{\mathrm{CO}, 0} \mathrm{~kg} \mathrm{~m}^{-3} \\
\text { Catalytic reactor diameter, } \mathrm{d}_{\mathrm{r}} \mathrm{m}\end{array}$ & $\begin{array}{l}400 \\
400 \\
1.011 \\
2.367 \times 10^{-2} \\
2.561 \times 10^{-4} \\
0.145 \\
0.052 \\
0.000 \\
0.000 \\
0.100 \\
0.000 \\
0.032\end{array}$ \\
\hline Gas properties & $\begin{array}{l}\text { Void fraction of the gaseous phase, } \varepsilon_{\mathrm{g}}(-) \\
\text { Density of the gaseous phase, } \rho_{\mathrm{g}} \mathrm{kg} \mathrm{m}^{-3} \\
\text { Diffusion coefficient of } \mathrm{C}_{7} \mathrm{H}_{8}, \mathrm{D}_{\mathrm{C} 7 \mathrm{H} 8} \mathrm{~m}^{2} \mathrm{~s}^{-1} \\
\text { Diffusion coefficient of } \mathrm{H}_{2} \mathrm{O}, \mathrm{D}_{\mathrm{H} 2 \mathrm{O}} \mathrm{m}^{2} \mathrm{~s}^{-1} \\
\text { Diffusion coefficient of } \mathrm{CO}, \mathrm{D}_{\mathrm{CO}} \mathrm{m}^{2} \mathrm{~s}^{-1} \\
\text { Diffusion coefficient of } \mathrm{H}_{2}, \mathrm{D}_{\mathrm{H} 2} \mathrm{~m}^{2} \mathrm{~s}^{-1} \\
\text { Diffusion coefficient of } \mathrm{CH}_{4}, \mathrm{D}_{\mathrm{CH} 4} \mathrm{~m}^{2} \mathrm{~s}^{-1} \\
\text { Diffusion coefficient for } \mathrm{CO}_{2}, \mathrm{D}_{\mathrm{CO} 2} \mathrm{~m}^{2} \mathrm{~s}^{-1}\end{array}$ & $\begin{array}{l}0.360 \\
0.0756 \\
1.571 \times 10^{-5} \\
2.113 \times 10^{-5} \\
1.567 \times 10^{-5} \\
6.915 \times 10^{-6} \\
3.337 \times 10^{-5} \\
8.987 \times 10^{-6} \\
\end{array}$ \\
\hline $\begin{array}{l}\text { Properties of the solid } \\
\text { phase }\end{array}$ & $\begin{array}{l}\text { Void fraction of the solid phase, } \varepsilon_{\mathrm{s}}(-) \\
\text { Density of the solid phase, } \rho_{\mathrm{s}} \mathrm{kg} \mathrm{m}^{-3} \\
\text { Solid particle diameter, } \mathrm{d}_{\mathrm{p}} \mathrm{m}\end{array}$ & $\begin{array}{l}0.614 \\
1.250 \times 10^{3} \\
0.00046\end{array}$ \\
\hline $\begin{array}{l}\text { Heat of reactions } \\
\text { effectiveness factor }\end{array}$ & $\begin{array}{l}\text { Heat of react. for react. (1), } \Delta \mathrm{H}_{\mathrm{r}, 1} 850{ }^{\circ} \mathrm{C}, \mathrm{kJ} \mathrm{mol}^{-1} \\
\text { Heat of react. for react. (2), } \Delta \mathrm{H}_{\mathrm{r}, 2} 850{ }^{\circ} \mathrm{C}, \mathrm{kJ} \mathrm{mol}^{-1} \\
\text { Heat of react. for react. (3), } \Delta \mathrm{H}_{\mathrm{r}, 3} 850{ }^{\circ} \mathrm{C}, \mathrm{kJ} \mathrm{mol}^{-1} \\
\text { Effectiveness factor of reaction (1), } \eta_{1} \\
\text { Effectiveness factor of reaction (2), } \eta_{2} \\
\text { Effectiveness factor of reaction (3), } \eta_{3}\end{array}$ & $\begin{array}{l}+639.291 \times 10^{3} \\
+206.191 \times 10^{3} \\
-89.231 \times 10 \times 10^{3} \\
0.067 \\
0.073 \\
0.573\end{array}$ \\
\hline
\end{tabular}




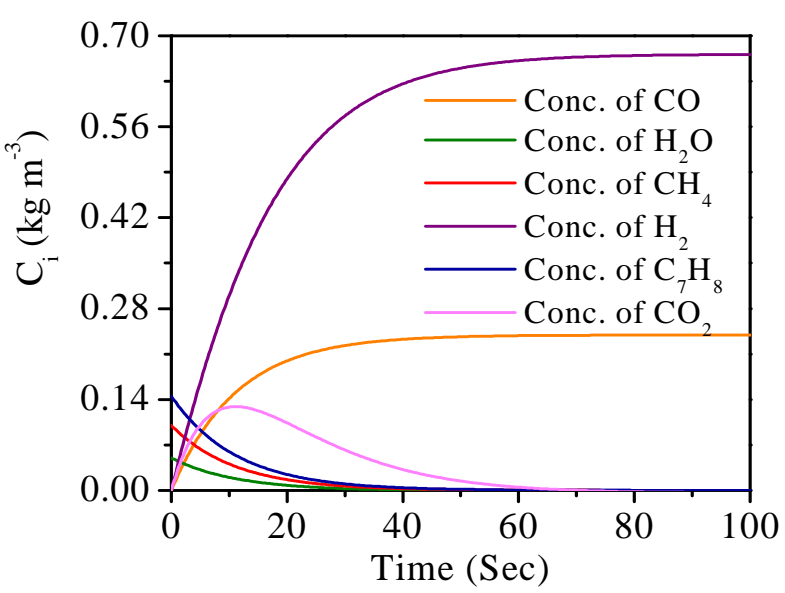

Figure 3: Profiles of the concentrations of species $\mathrm{C}_{7} \mathrm{H}_{8}, \mathrm{H}_{2} \mathrm{O}, \mathrm{H}_{2}, \mathrm{CH}_{4}, \mathrm{CO}$ and $\mathrm{CO}_{2}$ in function of time at the exit of the CFBR on the conditions: $\mathrm{z}=1 \mathrm{~m}, \mathrm{Q}_{\mathrm{g}}=6.87 \times 10^{-6}$ $\mathrm{m}^{3} \mathrm{~s}^{-1}$ and at $\mathrm{t}=8 \mathrm{sec}$ of computer time

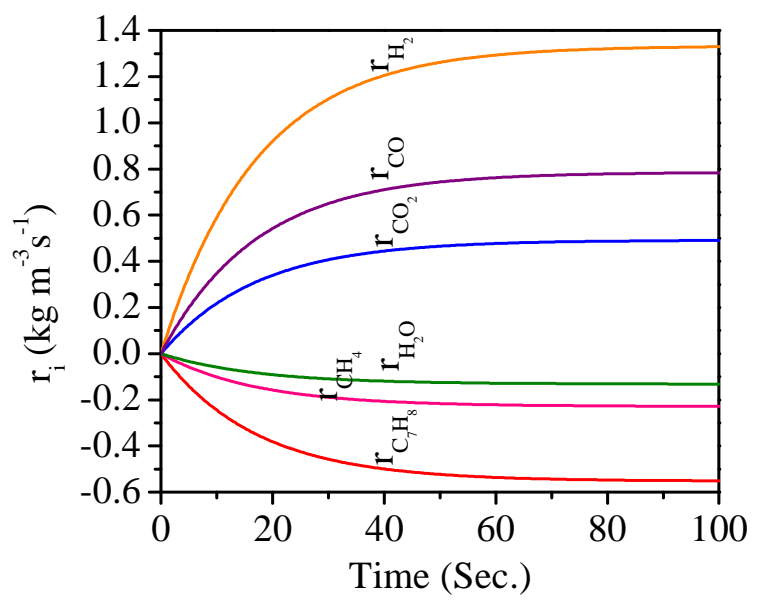

Figure 4: Profiles of net rates of species $\mathrm{C}_{7} \mathrm{H}_{8}, \mathrm{H}_{2} \mathrm{O}, \mathrm{H}_{2}, \mathrm{CH}_{4}, \mathrm{CO}$ and $\mathrm{CO}_{2}$ in function of time at the exit of the CFBR under the following conditions: $\mathrm{z}=1 \mathrm{~m}, \mathrm{Q}_{\mathrm{g}}=6.87 \times 10^{-6}$ $\mathrm{m}^{3} \mathrm{~s}^{-1}$ and at $\mathrm{t}=8 \mathrm{sec}$ of computer time

Figure 3 reports the evolution of $\mathrm{C}_{7} \mathrm{H}_{8}, \mathrm{H}_{2} \mathrm{O}, \mathrm{CO}, \mathrm{H}_{2}, \mathrm{CH}_{4}$, and $\mathrm{CO}_{2}$ versus the time variable at the output of the LF. Chemical species $\mathrm{CO}, \mathrm{CO}_{2}$ and $\mathrm{H}_{2}$ are produced from the initial values of $\mathrm{C}_{\mathrm{CO}}=0.00, \mathrm{C}_{\mathrm{H} 2}=0.00$ and $\mathrm{C}_{\mathrm{CO} 2}=0.00$ until reaching a maximum value at the operating conditions adopted, while chemical species $\mathrm{C}_{7} \mathrm{H}_{8}, \mathrm{H}_{2} \mathrm{O}$ and $\mathrm{CH}_{4}$ have been consumed from the initial values $\mathrm{Y}_{\mathrm{C} 7 \mathrm{H} 8}=0.148, \mathrm{Y}_{\mathrm{H} 2 \mathrm{O}}=0.052$ and $\mathrm{Y}_{\mathrm{CH} 4}=0.101$. Chemical species $\mathrm{H}_{2}$ and $\mathrm{CO}$ in \pm 80 s. reached steady state, while the chemical species $\mathrm{CO}_{2}$ reached a maximum and then decreases reaching a steady state at \pm 70 sec. For chemical species $\mathrm{C}_{7} \mathrm{H}_{8}, \mathrm{H}_{2} \mathrm{O}$ and $\mathrm{CH}_{4}$, it is observed that they were completely consumed between (20-40) sec.

The Figure 4 shows the net rates of each chemical species relative to the time variable at the output of the LF. The net rates $\mathrm{r}_{\mathrm{H} 2}, \mathrm{r}_{\mathrm{CO}}, \mathrm{r}_{\mathrm{CO} 2}$ reported an increase between $0.00 \mathrm{sec}$. to $100 \mathrm{sec}$. due to increased production of chemical species $\mathrm{H}_{2}, \mathrm{CO}$ and $\mathrm{CO}_{2}$ at $800^{\circ} \mathrm{C}$. The net rates $\mathrm{r}_{\mathrm{C} 7 \mathrm{H} 8 \text {, }}$ $\mathrm{r}_{\mathrm{CH} 4}$ and $\mathrm{r}_{\mathrm{H} 2 \mathrm{O}}$ suffer because of decreasing consumption of chemical species $\mathrm{C}_{7} \mathrm{H}_{8}, \mathrm{CH}_{4}$ and $\mathrm{H}_{2} \mathrm{O}$ at $800^{\circ} \mathrm{C}$.

\section{CONCLUSIONS}

Conducted in the context of reform of the line of aromatic components, this research will resort numerical methodology in order to carry out the development of the process in isothermal catalytic reactor of LF. In conditions allowed for this research, the method of Runge-Kutta Gill was used to predict chemical species $\left(\mathrm{C}_{7} \mathrm{H}_{8}, \mathrm{H}_{2} \mathrm{O}, \mathrm{CO}, \mathrm{H}_{2}, \mathrm{CH}_{4}\right.$, and $\left.\mathrm{CO}_{2}\right)$. The development of computer code to process and analyze the behavior of the variables in this research allowed the following conclusions: 
- The model developed for the LF led to calculations of optimized concentrations of chemical species $\mathrm{H}_{2}, \mathrm{CO}$ and $\mathrm{CO}_{2}$, validation confirmed by comparing the optimized results of this research and the results obtained by Zhao et al., (2010);

- Consumption and production have shown the evolution of chemical species of $\mathrm{C}_{7} \mathrm{H}_{8}, \mathrm{H}_{2}, \mathrm{CO}$, $\mathrm{H}_{2}, \mathrm{CH}_{4}$, and $\mathrm{CO}_{2}$ versus time.

- The net rates $\left(\mathrm{r}_{\mathrm{C} 7 \mathrm{H} 8}, \mathrm{r}_{\mathrm{H} 2 \mathrm{O}}, \mathrm{r}_{\mathrm{CO}}, \mathrm{r}_{\mathrm{H} 2}, \mathrm{r}_{\mathrm{CH} 4}\right.$ and $\left.\mathrm{r}_{\mathrm{CO} 2}\right)$ of each chemical species were calculated. Since the net rates $r_{\mathrm{CO}}, \mathrm{r}_{\mathrm{H} 2}$ and $\mathrm{r}_{\mathrm{CO} 2}$ showed in the Figure 1 increases, while the net rates $\mathrm{r}_{\mathrm{C} 7 \mathrm{H} 8 \text {, }}$ $\mathrm{r}_{\mathrm{CH} 4}$ and $\mathrm{r}_{\mathrm{H} 2 \mathrm{O}}$ reported in the Figure 1 decrease;

\section{ACKNOWLEDGMENTS}

The authors of this paper would like to thank CNPQ (National Council of Scientific and Technological Development) for the financial support given. (Process 48354/2012).

\section{REFERENCES}

Bona, S., Guillén, P. J., Alcalte, G., García, L., Bilbao, R. 2008, Toluene Steam Reforming Using Co-precipitated Ni/Al Catalysts Modified with Lanthanum or Cobalt, Chemical Engineering Journal, 137, 587-597.

Oliveira C.C.B., da Silva J.D., 2012, Dynamic modelling of the gasification region of a bubbling fluidized bed gasifier, Chemical Engineering Transactions, 29, 841-846, doi: 10.3303/CET1229141.

Silva J.D., Abreu C.A.M., 2012, Mathematical modeling of a three-phase trickle bed reactor. Brazilian Journal of Chemical. Engineering, 29(3), 567-576, doi:10.1590/S010466322012000300014.

Silva J. D., 2012, Dynamic Modelling for a trickle-bed reactor using the numerical inverse Laplace transform technique. Procedia Engineering., 42, 454-470. doi: 10.1016/j.proeng.2012.07.437.

Xiu, G.; Li, P.; Rodrigues, A. E.,2002, New Generalized for improving sorption-enhanced reaction process, Chemical Engineering Science, 58, 3425-3437.

Yao B. Y.; Anh N. P., Changkook R.; Vida S.; Jim S., 2007, Mathematical modelling of slow pyrolysis of segregated solid wastes in a packed-bed pyrolyser. Fuel, 86, 169-180.

Zhao B.; Zhang X.; Chem L.; Qu R.; Meng G.; Yi X.; Sun L., 2010, Steam Reforming of Toluene as Model Compound of Biomass Pyrolysis Tar for Hydrogen. Biomass and Bioenergy, 34, 140-144. 